УДК 355.42:94(73)

DOI: 10.33099/2707-1383-2021-39-1-114-127

Дмитро Вімер

доктор філософських наук,

старший науковий співробітник,

головний науковий співробітник

Центру воєнно-стратегічних досліджень,

Національний університет оборони України

імені Івана Черняховського (Київ, Украӥна),

ORCID https://orcid.org/0000-0002-7330-1280

Електронна пошта:vdv_n@ukr.net

\title{
РОЗВИТОК КОНЦЕПЦІЇ ПОВІТРЯНО-НАЗЕМНОЇ ОПЕРАЦІЇ В АРМІЇ ОБОРОНИ ІЗРАЇЛЮ (ЦАХАЛ) У ВІЙНІ 1967 Р.
}

У статті проаналізовано концепцію повітряно-наземної операції, розроблену Армією Оброни Ізраїлю (ЦАХАЛ), та окремі аспекти ї̈ реалізаџії під час Шестиденної війни (1967 р.). Наголос зроблено на основних концептуальних елементах оперативного застосування військ (сил) та розвитку принципів тактики «блискавичної війни». Показано, щуо на конщептуальному рівні в ЦАХАЛ було визначено та обтрунтовано певні елементи розроблення і впровадження розвідувально-ударної бойової системи.

Ключові слова: Армія Оборони Ізраїлю (ЦАХАЛ), «блискавична війна», концепція повітряно-наземних операцій, локальні війни, форми і способи збройної боротьби, оперативне мистецтво, Шестиденна війна.

Постановка проблеми. Зміни концептуальних принципів ведення війн мають на меті забезпечення не тільки досягнення максимальної ефективності військ (сил) при виконанні бойових завдань, але й підвищення рівня боєготовності ЗС до відбиття раптового нападу противника. У цьому аспекті раптовість як один 3 основних принципів оперативного мистецтва залишається актуальною 3 точки зору способів досягнення тактичної, оперативної і стратегічної переваги над противником. Поєднання «класичних» принципів ведення збройної боротьби з сучасними концепціями оперативного застосування військ (сил), зокрема концепції повітряно-наземної операції(далі-ПНО), $\epsilon$ актуальним питанням в аспекті розвитку оперативного мистецтва, вирішення якого потребує звернення до історичного досвіду ведення війн. Одним 3 яскравих прикладів 
такого поєднання є розвиток концепціï ПНО, здійснений командуванням Армії Оборони Ізраїлю (далі ЦАХАЛ) під час ведення Шестиденної війни (1967р.). Досягнення у розвитку оперативного мистецтва ЦАХАЛ підкреслюються тим, що основні положення концепції ПНО, які враховували тактику військ (сил) ЦАХАЛ, були розвинені наприкінці 70-х pp. (Skinner, D. 1988), результатом чого стало офіційне затвердження НАТО на початку 1980-х рр. концепції ПНО для інстанцій від армійського корпусу і вище (Семон, Б. 2012) та концепції боротьби $з$ другими ешелонами (НАTO, FOFA) (Чернов, В. 2012; Romjue, J. 1984). Основні принципи концепції ПНО, розроблені та реалізовані ЦАХАЛ під час Шестиденної війни, також стали підгрунтям розвитку американської концепції «глибокого ураження», але США фактично лише доповнили концепцію ПНО поняттям оперативного рівня бойових дій (Czege, de H. 1982; Operations FM. 1982). Підтвердженням ефективності цієї концепції оперативного застосування військ (сил) стали операції об' єднаних сил НАТО в зоні Перської затоки («Буря в пустелі», 1990-1991 рр.) та Югославії («Союзницька сила», 1999 р.) (Benson, В. 2012). Крім того, війна в Перській затоці підкреслила необхідність перегляду основних принципів концепцій ведення збройної боротьби - відхід від масового застосування сухопутних військ, переорієнтація на переважне застосування підрозділів спеціального призначення, що досягається постійним оновленням ВПС, оснащенням військ (сил) протиракетними комплексами, модернізацією засобів РЕБ, систем ППО та ПРО.

Аналіз публікацій. Питанням концепції ПНО в контексті розвитку оперативного мистецтва, змін форм i способів ведення збройної боротьби присвячені праці В. Волобуєва (Волобуев, В. 1984), Б. Семона (Семон, Б. 2012), В. Телелима (Телелим, В. 2012), С. Навеха (Naveh, S. 1997), Дж. Ромжю (Romjue, J. 1984), Д. Скіннера (Skinner, D. 1988). У працях Т. Дюпюї (Dupuy, T. 1992), Е. Лібермана (Lieberman, E. 1995), В. Лакуера (The Israel-Arab reader. 1995), Б. Рубіна (The Israel-Arab reader. 1995) розглядались окремі питання оперативного застосування військ (сил) Армією оборони Ізраїлю (ЦАХАЛ) під час ведення Шестиденної війни. Проте, питання еволюції концептуальних елементів оперативного застосування військ (сил) і розвитку принципів тактики «блискавичної війни» у зв’ язку із плануванням та проведенням ПНО залишаються малодослідженими.

Метою статті $\epsilon$ аналіз окремих аспектів реалізації концепції ПНО, ii розвиток в контексті оперативного мистецтва у зв' язку з принципами тактики «блискавичної війни».

Виклад основного матеріалу. Розвиток концепції ПНО безпосе- 
редньо пов'язаний 3 тактикою, яку застосувала Армія оборони Ізраїлю у Шестиденній війні. Ця тактика була пов'язана 3 розробленою в $\mathrm{Pa}$ дянському Союзі теорією глибокої наступальної операції (Телелим, В. 2012), яка намагалася вирішити проблеми прориву оборони противника на всю оперативну глибину і розвитку тактичного успіху в оперативній, віддаючи пріоритет застосуванню мобільних угруповань наземних військ, повітряних десантів, ВПС i засобів розвідки, зокрема, РЕБ на всій оперативній глибині противника (Кирилов, В 1975; Naveh, S. 1997; Romjue, J. 1984). У межах реалізації положень теорії глибокої наступальної операції та теорії «блискавичної війни» Ізраїль розробив власну стратегію блискавичного почергового розгрому держав-членів коаліції арабських країн $з$ нанесенням головного удару по Сгипту. План реалізаціï стратегіï передбачав нанесення ураження військам Сгипту та Йорданії, вихід до Суецького каналу та p. Йордан, оволодіння Синайським півостровом та західним берегом p. Йордан 3 подальшим розгортанням наступу проти Сирії в районі північніше та південніше Тиверіадського озера рис. 1 (Dupuy, Т. 1992, p. 262). В контексті зазначеної стратегії загальний оперативний замисел командування ЦАХАЛ передбачав нанесення превентивного удару по об' єктах військової авіації противника з метою заподіяння їй максималь- них втрат і захоплення переваги у повітрі. На підгрунті ретельного аналізу можливостей військ коаліції арабських країн командуванням ЦАХАЛ в якості головного засобу досягнення оперативної та стратегічної переваги над противником був обраний принцип раптовості. При цьому було враховано кількісну перевагу збройних сил Єгипту та військ (сил) коаліції арабських країн в озброєнні та живій силі. В результаті неочікуваного для противника початку бойових дій у найбільш доцільному угрупованні повністю боєздатними військами у найменш очікуваному напрямі головного удару і часі початку дій війська (сили) ЦАХАЛ створити вигідну для себе оперативну обстановку та фактично знищили можливість організованої протидії з боку військ (сил) коаліції арабських країн.

Вирішуючи одну з найважливіших проблем оперативного мистецтва, яка стосується підготовки і ведення перших операцій на початку війни, командування ЦАХАЛ в якості визначальної умови досягнення успіху під час Шестиденної війни (1967р.) визначило перехоплення ініціативи на всіх напрямах, що стало одним $з$ головних стратегічних завдань військ (сил) та було враховано у плані наступальної операції на Синаї. Оперативний план грунтувався на використанні всіх переваг принципу раптовості, ранньому досягненні панування у повітрі, ранній і рішучій взаємодії 3 основними силами 
M E D I T E R R A N E A N

S E A

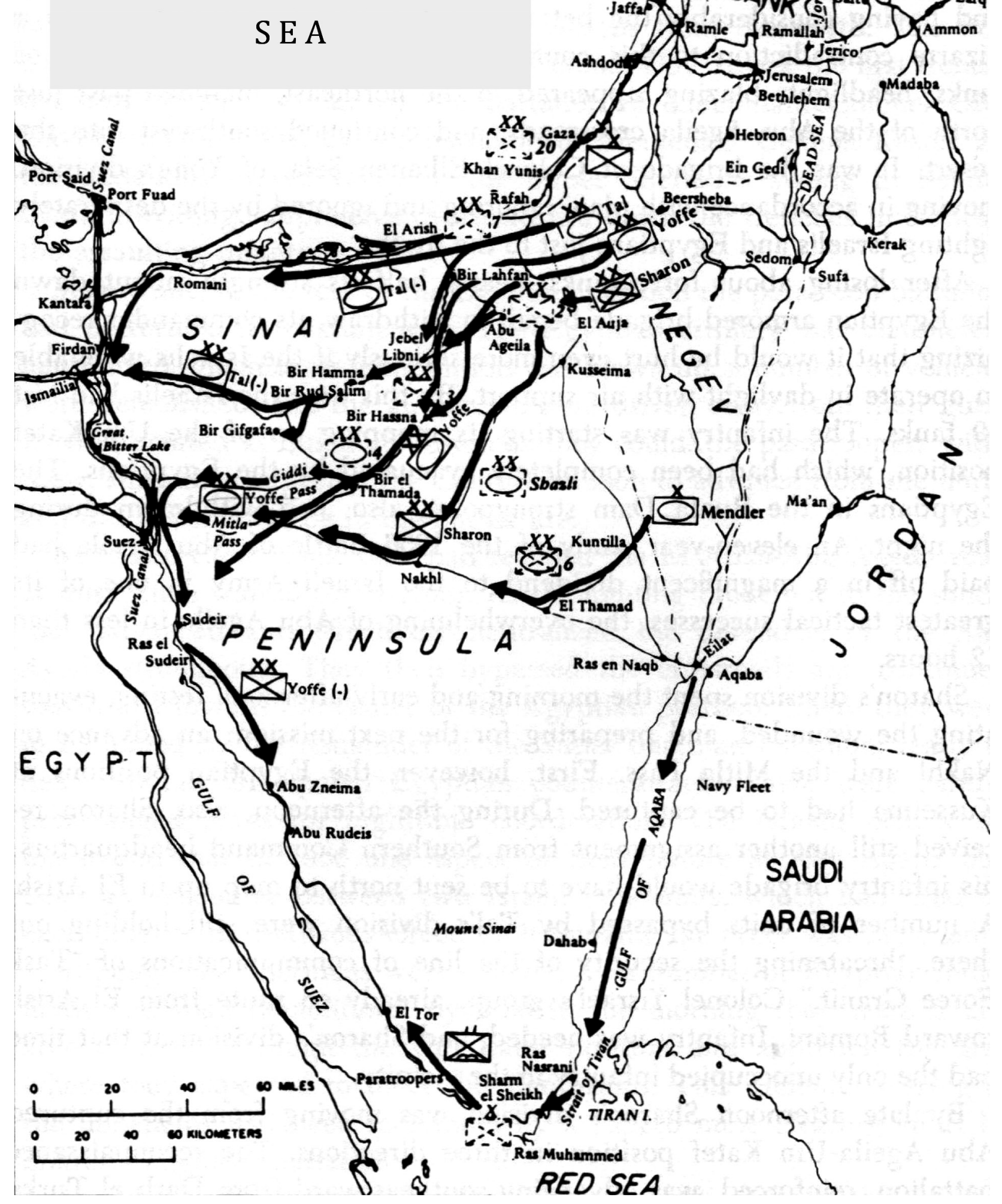

Puc. 1. Загальний оперативний план ЦАХАЛ на Синаї, 1967 р. 
противника на найбільш можливому віддаленні від власних кордонів, фактично орієнтуючись на стрімке просування військ (сил) ЦАХАЛ на максимальну відстань в оперативну глибину противника, захоплення ініціативи та створення оперативної переваги.

Загальна оперативна концепція, яка була розроблена начальником штабу ЦАХАЛ генерал-майором Іцхаком Рабіном, передбачала в якості ключового заходу раптовий початок бойових дій на суходолі одночасно iз запровадженням практики ранкових масових польотів літаків ВПС у західному районі Середземного моря 3 метою зниження пильності ППО Єгипту.

Деталізація оперативної концепції I. Рабіна була здійснена у плані генерала Іешайяху Гавіша, який передбачав чотири основні етапи (Dupuy, T. 1992, p. 243-244):

1. Прорив лінії єгипетського фронту у напрямі Рафах — Ель-Аріш силами дивізії (угда) генерала Ізраеля Таля; у напрямі Абу Агейла УмКатеф силами дивізії генерала Аріеля Шарона.

2. Введення дивізії генерала Авраама Йоффе в залежності від оперативної обстановки або у розрізі дивізій I. Таля і А. Шарона, або південніше зони оперативної відповідальності дивізії А. Шарона 3 метою проникнення на значну відстань в оперативну глибину єгипетських військ на Синаї з подальшим роз- громом другої лінії оборони в районі Джебель Лібні.

3. Зосередження бронетанкових частин дивізій I. Таля, А. Шарона i А. Йоффе в оперативному районі Нахл — Мітла Пасс — Бір Гіфгафа.

4. Наступ у напрямі Суецького каналу і захоплення Шарм-ель-Шейха.

Оперативна концепція і план розгрому єгипетських сил в глибині Синаю визначали напрямом головного удару північ в обхід Ейлату. Реалізація концепції підтримувалась планом дезінформації противника, який передбачав прикриття прихованого розташування трьох дивізій на південному заході Негев демаскованим розташуванням декількох батальйонів і бригади на півдні та їх відкритого висування в район кордону. Прикриття забезпечувалось активними польотами легких літаків та вертольотів вздовж кордону на півдні. Метою заходів було запевнення єгиптян про заплановане вторгнення Ізраїлю з півдня в обхід сектору Гази (The Israel-Arab reader. 1995).

У рамках розробленої оперативної концепції командування ЦАХАЛ визначило в якості найбільш ефективного способу застосування військ (сил) нанесення раптових блискавичних ударів по основних угрупованнях військ (сил) противника на всій оперативній глибині, в результаті чого ефективність повітряної фази всієї операції була настільки високою, що єгипетські війська (сили) не отримали необхідного їм часу ані 
для прийняття контрзаходів, ані для винайдення засобів протидії противнику. Ізраїль у повному обсязі використав фактор раптовості, поєднавши зусилля всіх підрозділів ЦАХАЛ, задіяних у проведенні повітряно-наземної операції проти Сгипту, завдяки відмові від створення суцільних фронтів, істотному підвищенню темпів бойових дій, які підтримувались створенням мобільних тактичних ударних з'єднань за активної підтримки повітряних десантів, які руйнували систему тилу і відтягували на себе значну частку сил та засобів противника, необхідних йому на лінії безпосереднього зіткнення. Застосування десанту в різних формах i способах (наприклад, застосування бригадних тактичних груп, які діяли за принципами тактичного десанту, танкових груп тощо) мало одне з вирішальних значень. Рішучі й зухвалі дії десанту, як правило, призводили до втрати командуванням єгипетських військ (сил) розуміння оперативної обстановки, дезорганізації загальної і часткової системи управління військами (силами), діяльності штабів.

Весь запланований комплекс заходів забезпечив ЦАХАЛ раптовість, яка була ефективно використана для розвитку оперативної і стратегічної переваги над противником.

Досягнення переваг раптовості здійснювалось у межах комплексної взаємодії всіх видів забезпечення 3 особливим акцентом на непрямих діях розвідки та авіації, які були більш успішними порівняно 3 прямими, широким використанням ПДВ та їх можливостей у напрямі створення необхідних умов для успішного виконання тактичного замислу щодо використання основних сил. Це здійснювалось за безумовної підтримки досягнення оперативної раптовості шляхом застосування системи відволікаючих, демонстративних, імітаційних, дезінформаційних, маскувальних, дезорганізаційних заходів, характерних для ПНО, які поєднувалися 3 класичним принципом випередження противника в мобілізаційному й оперативному розгортанні збройних сил. Командування ЦАХАЛ також активно застосовувало передбачені концепцією ПНО методи інформаційно-психологічного протиборства (Волобуєв, В. 1984 , с. 32), які дозволили отримати перевагу над противником ще до початку бойових дій. Ефективність застосування інформаційних методів в межах концепції ПНО засвідчила, що інформаційна насиченість ведення збройної боротьби набуває визначального характеру на ТВД, створюючи передумови проведення об'ємних операцій, беручи свій початок та отримуючи логічне завершення в розробці теорії та концепцій воєнних операцій. Відповідно до цього концептуального положення ЦАХАЛ орієнтувався на отримання розвідувальної інформації, яка слугувала основним джерелом при- 
йняття рішень і постановки бойових завдань при застосуванні військової авіації, що завдавала максимальних втрат у військовій техніці та живій силі противника, створюючи умови для швидкого просування наземних військ в глибину оперативного простору противника й виконання бойових завдань на його території.

Правильність обраних способів ведення бойових дій була підкреслена результативністю та ефективністю повітряно-наземної операції, розробленої та проведеної військами (силами) ЦАХАЛ на початку Шестиденної війни. Концепція ПНО визначила можливість реалізації основних принципів «блискавичної перемоги», на яких базувалась стратегія і тактика ЦАХАЛ. Хоча успіх ЦАХАЛ у воєнній кампанії 1967 р. суттєво залежав від проведення на початку війни повітряної операції, яка мала забезпечити вигідні оперативні й стратегічні умови розвитку наземної операції. Пріоритетом такого розподілу повітряно-наземної операції на декілька етапів стала необхідність урахування часового обмеження діяльності моменту раптовості, адже швидкоплинність повітряно-наземної операції вирішується саме фактором часу. Поряд з цим, ураховуючи, що ефективна організація ППО та ПРО на ТВД (навіть локальному) здатна суттєво обмежити потенціал наступальної зброї, ЦАХАЛ зробив ставку на застосування сил і засобів ВПС, хоча, як підкреслюють аналі- тики, «ані єгиптяни, ані ізраїльтяни не вірили, що військова авіація буде ефективною проти захищених наземних цілей, й водночас вони не передбачали легкості, 3 якою ізраїльські сили зможуть проникнуть до Єгипту» (Lieberman, Е. 1995, p. 20). Загально прийнятою стала думка про те, що «повітряні судна можуть бути ефективними в стратегічних операціях, але в тактичних операціях, поза умовами ведення загальної війни, ефект буде обмежений, особливо для винищувачів, яким допомагає характер місцевості, на якій вони воюють, та їх підготовка для захисту себе від повітряних атак» (The Israel-Arab reader. 1995, p. 418). Відтак, відкритим залишалося питання про ефективність побудови єгипетської системи та іiі реальних можливостей протидіяти ВПС Ізраїлю, які були головною ударною силою ЦАХАЛ при веденні «блискавичної» війни та військових операцій будь-якого масштабу (починаючи з війни 1956 р.), а основним призначенням ВПС та ППО було визначено проведення повітряних операцій, завоювання панування у повітрі, безпосередня підтримка сухопутних військ та ВМС, повітряна розвідка, забезпечення висадки повітряного десанту.

Завдяки успішним діям розвідки ізраїльське командування отримало достовірні дані про аеродромну мережу, позиції зенітних та ракетних частин ППО, місця розташування складів, штабів, вузлів, ліній зв'язку 
противника. Крім цього, були отримані достовірні розвідувальні дані про можливості, порядок застосування, дислокацію збройних сил Єгипту. Інформація про радіочастоти, порядок виходу в ефір, позивні пілотів тощо створила умови для завоювання оперативної переваги над противником у повітрі, внаслідок чого ЦАХАЛ отримав можливість безпосередньо втручатися в дії ВПС Єгипту, не тільки створюючи радіоперешкоди, але й навіть віддавати накази пілотам бойових літаків збройних сил Єгипту (Dupuy, T. 1992, p. 246). Фактично однією з основних помилок вищого військово-політичного керівництва Сгипту став «низький рівень очікувань єгипетського командування відносно військово-повітряних сил Ізраїлю» (Lieberman, Е. 1995, p. 21), який виник на підставі переоцінки власних можливостей: упевненості у високій боєздатності своїх збройних сил винятково як результату їх підготовки радянськими військовими спеціалістами, переоцінка потенціалу та можливостей радянської зброї ППО тощо.

Звернення головної уваги до основних принципів концепції ПНО забезпечило гнучкість тактики у поєднанні з випередженням противника в мобілізаційному й оперативному розгортанні збройних сил, високий рівень маневреності військ (сил) і успішне протистояння ЦАХАЛ переважаючим військам (силам) противника, які діяли згідно $з$ устале- ними принципами теорії глибокої операції, покладаючись на переваги ешелонованої оборони. Розуміючи тактику єгипетських військ (сил), передбачену розробленою в Радянському Союзі теорією глибокої операції, ЦАХАЛ застосував нові способи організації та ведення операцій, які стали неочікуваними для противника, що забезпечило досягнення найбільшої оперативної і тактичної раптовості й поразку противника меншими силами. Успіх ЦАХАЛ при просуванні в оперативну глибину противника розвивався за рахунок широкого застосування маневру на вільному оперативному просторі, який утворився внаслідок неузгодженості ведення коаліцією арабських країн воєнних дій поряд із відсутністю єдиного плану війни, що дозволило Ізраїлю почергово наносити удари по військах противника на різних напрямах. Не готові до ведення активної маневреної війни, війська арабських країн не змогли використати наявні сприятливі умови оперативної обстановки й реалізувати власні тактичні замисли, оскільки висока динаміка змін оперативної і тактичної обстановки в умовах активної маневреної війни завжди потребує високого рівня підготовки до управління військами. Останнього підрозділам коаліції об'єднаних арабських країн бракувало у тому числі й внаслідок успішного виконання військами (силами) Ізраїлю завдань 3 дезорганізації управління. Але найбільш ефективним вияви- 
лося раптове вклинення і просування в оперативну глибину противника, нанесення ударів по військах противника 3 тилу й флангів із застосуванням передових ударних груп і десантів (повітряних, морських). Також на основі застосування повітряних десантів і маневрених груп військам (силам) ЦАХАЛ вдалось суттєво підвищити розвідувальні й ударні можливості по цілях на всій оперативній глибині противника.

У цілому успіх Ізраїлю у воєнній кампанії 1967 р. був пов'язаний з декількома важливими факторами, що забезпечили повну перемогу військ (сил) ЦАХАЛ над противником у найкоротші строки. Так, на відміну від Єгипту, Ізраїлю не потрібно було здійснювати оперативне розгортання військ (сил) у повному обсязі. Ізраїль також відмовився від створення крупних оперативних угруповань військ (сил) на ТВД, основними заходами визначивши зайняття військами (силами) вихідних районів для наступу. 3 метою оптимізації управління військами (силами) у ЦАХАЛ було суттєво обмежене оперативне підпорядкування, що передбачало дії всіх підрозділів у рамках виконання єдиного замислу операції та сприяло підвищенню ефективності оперативного забезпечення. Досягнення оперативного успіху при проведенні наземного етапу ПНО забезпечувалось широким застосуванням повітряних i тактичних десантів, дії яких призводили до майже повної втрати ко- мандуванням Сгипту оперативності управління військами (силами), що підтвердило ефективність використання ПДВ та їх можливостей у забезпеченні оперативної раптовості та створенні умов для успішного виконання тактичного замислу щодо використання основних сил. Фактично, з огляду на те, що концепція ПНО передбачає скоординоване застосування сухопутних військ та ВПС, характерним для дій військ (сил) ЦАХАЛ під час Шестиденної війни стало поєднання принципів раптовості, мобільності, активності, зосередження зусиль, узгодженості дій, глибини, швидкості та захоплення стратегічної ініціативи (перш за все, за допомогою ВПС).

Фактично, готовність і здатність військ (сил) до самостійних дій значною мірою визначила характер і перебіг подій під час Шестиденної війни, коли висока динаміка, маневреність та локальна обмеженість бойових дій (ix локально-зосереджений характер), що проводились військами (силами) ЦАХАЛ, створили найбільші труднощі, а інколи й нездоланні перешкоди для єгипетських збройних сил, війська яких втрачали управління, а командний склад виявив майже повну відсутність навичок ведення бою в умовах швидкоплинних змін оперативної обстановки.

Висновки. У рамках інтерпретації командуванням ЦАХАЛ концепції ПНО на етапі підготовки і початку проведення повітряно-наземної опе- 
рації визначальна роль відводилася ВПС. Внаслідок того, що під впливом об'єктивних умов ведення бойових дій, ураховуючи, що Близькосхідний ТВД, на якому арабські країни мали значну чисельну перевагу за кількістю сил та засобів, характеризувався наявністю широких можливостей для них, Ізраїль майже одразу відмовився від застосування сил ВПС для прикриття наземних частин і підрозділів з повітря, конфігурація концепції ПНО набула нового змісту. Ключовими концептуальними принципами, які були реалізовані ЦАХАЛ під час Шестиденної війни, й класифікують повітряно-наземну операцію, стали: досягнення інформаційної переваги над противником засобами розвідки; завоювання панування в повітрі шляхом випереджального знищення оперативних сил (можливостей) авіації з одночасним придушенням або знищенням системи ППО противника; перехід до активної стадії наземної операції та завоювання вогневої переваги за підтримки всіх засобів ВПС на всій оперативній глибині противника.

Теоретична позиція обгрунтування характеру ймовірних бойових дій в умовах якісних змін можливостей військової техніки враховувала кількісну перевагу противника у силах та засобах, що забезпечує можливість створювати оперативний резерв, який може бути введений у бій у необхідний момент задля нанесення вирішального удару по противнику.
Створення такого резерву у другому ешелоні вказує на можливість збереження боєздатності військ противника навіть при понесенні військам (силам) його першого ешелону суттєвих втрат. Відтак, головним завданням оперативного застосування військ (сил) за таких умов виявилось одночасне ураження всіх ешелонів угруповань противника силами i засобами сухопутних військ та ВПС за безпосередньої підтримки розвідки, системи ППО, далекобійної артилерії та РСЗВ, засобами точкового ураження тощо. Внаслідок цього, на концептуальному рівні було визначено та обгрунтовано певні елементи розроблення і впровадження розвідувально-ударної бойової системи, яка застосовувалась ЦАХАЛ під час Шестиденної війни, коли найбільш вдалими були вертикальне і флангове охоплення військ противника поряд 3 одночасним нанесення ударів не тільки по угрупованнях сил і засобів противника на лінії безпосереднього зіткнення, але й у його оперативному тилу. Для цього здійснювався стрімкий маневр в оперативну глибину противника 3 метою блокування, дезорганізації його бойових порядків, резервів, нанесення ударів по другому ешелону військ (сил) або тиловій зоні. Одним з важливих елементів розвитку тактики в межах проведення повітряно-наземної операції стала така нова форма ведення бойових дій, що була застосована до підрозділів військ (сил) противника, 
які здійснювали прорив, як гонитва, в якій брали участь розгорнуті підрозділи сухопутних військ і патрульні підрозділи.

Не маючи ресурсної можливості вести тривалі бойові та воєнні дії, ЦАХАЛ наразі зберігає орієнтацію на перемогу у швидкоплинній війні, шляхи досягнення якої визначені концепцією ПНО та тенденціями іiі розвитку, що потребує удосконалення структури управління військами (силами), спрямованого на оптимізацію і прискорення процесу прийняття оперативних рішень. Водночас змінюються основні принципи концепцій оперативного застосування військ (сил), в яких головна роль відводиться проведенню спеціальних операцій на власній території та території противника силами і підрозділами спеціального призначення у поєднанні із застосуванням основних сил $\mathrm{i}$ засобів збройних сил держави.

Наразі концепція блискавичної війни й концептуальне переосмислення проведення повітряно-наземних операцій знаходить відображення й втілюється у тактиці ЦАХАЛ при проведенні антитерористичних операцій, яка передбачає рішучі й швидкі дії щодо захоплення ключових позицій й «зачисток» у визначених районах зосередження терористичних угруповань, що забезпечується атаками з повітря (повітряні бомбардування), наземними (рейди) та морськими атаками. ВПС Ізраїлю застосовує при проведенні повітряних атак увесь спектр озброєння, створюючи сприятливі умови для проведення наземних рейдів та морських атак, які, як правило, здійснюються тільки в окремих випадках. Нове концептуальне бачення застосування військ (сил) знайшло відображення у сучасній воєнній доктрині Ізраїлю, згідно з якою ЦАХАЛ бере участь в оперативних заходах, пов'язаних 3 антитерористичною діяльністю (наприклад, операція «Літанія», Південний Ліван, 1978 р.). Проте це питання потребує окремих досліджень.

\section{СПИСОК ВИКОРИСТАНИХ ДЖЕРЕЛ І ЛІТЕРАТУРИ}

Волобуев, В. (1984). Воздушно-наземная операция (сражение). Зарубежное военное обозрение. № 7, с. 29-35.

Кирилов, В. (1975). Тактика ударных групп израильской авиации. Зарубежное военное обозрение. № 4, с. 51-54.

Семон, Б. (2012). Розвиток концепцій оперативного застосування військ (сил) США у 80-х роках XX - на початку XXI століть. Воєнно-історичний вісник. № 3 (5), с. 113-119.

Телелим, В. (2012). Деякі аспекти розвитку радянської воєнної стратегії (1945-1991рр.). Воєнно-історичний вісник. № 3 (5), с. 95-103. 
Чернов, В. (2012). Глубокая операция. Применение армиями США и Великобритании «новой концепции» в военных действиях НАТО. Армейский сборник: Научно-методический журнал МО РФ. № 9, с. 53-59.

Benson, B. (2012). The Evolution of the Army Doctrine for Success in the 21 st century. Military Review. March-April, p. 2-12.

Czege, de H. (1982). The New FM 100-5. Military Review. July, p. 53.

Dupuy, T., col. (1992). Elusive victory. The Arab-Israeli wars, 1947-1974. Dubuque, Iowa: Kendall/Hunt publishing company, $669 \mathrm{p}$.

Lieberman, E. (1995). Deterrence Theory: Success or Failure in Arab-Israeli Wars? Washington, DC: National Defense University, $81 \mathrm{p}$.

Naveh, S. (1997). From Central Battle to Airland Battle. In: Pursuit of Military Excellence: The Evolution of Operational Theory. London, New York: Frank Cass, p. 287-305.

Operations FM 100-5. (1982). Washington, DC: Headquaters Department of the Army, 188 p.

Romjue, J. (1984). From Active Defense to AirLand Battle: the Development of Army Doctrine, 1973-1982. Fort Monroe, Virginia: Historical Office, U. S. Army Training and Doctrine Command, 128 p.

Skinner, D. (1988). Airland Battle Doctrine. Alexandria, Virginia: Center of Naval Analyses, $45 \mathrm{p}$.

The Israel-Arab reader: A Documentary History of the Middle East Conflict. (1995). [Walter Laqueur and Barry Rubin, eds.]. New-York: Penguin Books, 686 p.

\section{REFERENCES}

Volobuev, V. (1984). Vozdushno-nazemnaya operacia (srazenie) [Air-land operation (battle)]. Zarubejnoe voennoe obozrenie. № 7, s. 29-35. [in Russian].

Kirilov, V. (1975). Tactica udarnyh grup izrailskoy aviacyi [Tactic of the shock group of Israeli aviation]. Zarubejnoe voennoe obozrenie. № 4, s. 51-54. [in Russian].

Semon, B. (2012). Rozvitok koncepcyi operativnogo zastosuvannia viysk (syl) SSHA u 80-hrokah XX - na pochatku XXI stolit [The conception of the USA troops (powers) operative using development in 80-s XX - at beginning XXI c.]. Voenno-istoricheskiy visnyk. № 3 (5), s. 113-119. [in Ukrainian].

Telelim, V. (2012). Deyaki aspecty rozvitku radianskoi voennoi strategyi (1945-1991 rr.) [Some aspects of the soviet military strategy development (1945-1991)]. Voenno-istoricheskiy visnyk. № 3 (5), s. 95-103. [in Ukrainian].

Chernov, V. (2012). Glubokaia operacia. Primenenie armyiami SSHA i Velikobritanyi "novoy koncepcyi" v voennyh deystviah NATO [Deep operation. Using the "new concepts" by the USA and Great Britain armies in military acts of NATO]. Armeyskiy sbornik. № 9, s. 53-59. [in Russian].

Benson, B. (2012). The Evolution of the Army Doctrine for Success in the 21 st century. Military Review. March-April, s. 2-12. [in English]. 
Czege, de H. (1982). The New FM 100-5. Military Review. July, p. 53. [in English].

Dupuy, T., col. (1992). Elusive victory. The Arab-Israeli wars, 1947-1974. Dubuque, Iowa: Kendall/Hunt publishing company, 669 p. [in English].

Lieberman, E. (1995). Deterrence Theory: Success or Failure in Arab-Israeli Wars? Washington, DC: National Defense University, 81 p. [in English].

Naveh, S. (1997). From Central Battle to Airland Battle. In: Pursuit of Military Excellence: The Evolution of Operational Theory. London, New York: Frank Cass, p. 287-305. [in English].

Operations FM 100-5. (1982). Washington, DC: Headquaters Department of the Army, 188 p. [in English].

Romjue, J. (1984). From Active Defense to AirLand Battle: the Development of Army Doctrine, 1973-1982. Fort Monroe, Virginia: Historical Office, U. S. Army Training and Doctrine Command, 128 p. [in English].

Skinner, D. (1988). Airland Battle Doctrine. Alexandria, Virginia: Center of Naval Analyses, 45 p. [in English].

The Israel-Arab reader: A Documentary History of the Middle East Conflict. (1995). [Walter Laqueur and Barry Rubin, eds.]. New-York: Penguin Books, 686 p. [in English].

\section{Dmitry Viter}

Doctor of Philosophical Sciences,

Senior researcher, Leading research fellow

of the Center for Military and Strategic Studies,

The National Defense University of Ukraine

named after Ivan Cherniakhovskyi

(Kyiv, Ukraine)

ORCID https://orcid.org/0000-0002-7330-1280

\section{DEVELOPMENT OF AIR-LANDING OPERATION'S CONCEPT IN ISRAELI ARMY OF DEFENCE (TCAHAL) IN WAR OF 1967}

The article deals with the concept of air-landing operation developed by Israeli Army of Defence (TCAHAL) and some aspects of its implementation in Six-Day War (1967). The main emphasis is on the conceptual elements of operational troops (forces) employment and the "Six-Day War" tactical principles development.

The readiness and ability of troops (forces) to act independently in the context of the war tactics were determined. In this case the nature and course of events during the Six-Day War was accounted, when the high dynamics, manoeuvrability, and locally limited fighting (their locally-focused character) that conducted by TCAHAL troops (forces) created the greatest difficulties for the Egyptian armed forces. 
This approach became the basis for interpretation by the TCAHAL command the air-land operation conception at the stage of preparation and beginning of the operation, in which the Air Force played a decisive role.

It is shown in the article that the theoretical position of command was based on the justification of the nature of the possible combat actions in the context of qualitative changes in the military capabilities, taking into account the quantitative advantage of the enemy forces and means. It provides the ability to create an operational reserve, which must be put into battle at the right time to strike a decisive blow at the enemy. The TCAHAL concept of air-land operation in framework of armored doctrine emphasized shock action and mobility, flexibility and aggressiveness. These were combined to make armored vehicles the principal ground-force elements in the course of war. There was a major change at the top level of TCAHAL on the eve of war. The change fundamental operational concepts (not only on the doctrinal level) made a significant effect. There were some key elements of the Israeli plan for offensive: surprise, early achievement of air superiority, early and decisive engagement with main enemy forces as far as possible. There were some extremely significant factors in TCAHAL concept of air-land operation: flexible; aggressive; dynamic; successful achievement of surprise; superiority in the air achieved by the superbly executed attacks; the achievement of information superiority over the enemy by the intelligence; the conquest of air supremacy by pre-emptively destroying the air force's operational (capabilities) while simultaneously suppressing or destroying the enemy air defence system; the transition to the active stage of ground operation and gaining the advantage of firing with the support of all the Air Force at the entire operational depth of the enemy.

Key words: concept of air-landing operation, local wars, forms and methods of warfare, Israeli Army of Defence (TCAHAL), "flashing" war, operational art, Six-Day war. 